\title{
A Man in a Vessel Once More
}

\author{
KAREL C. INNEMÉE
}

\begin{abstract}
In one of the paintings in the Central Church of Abdallah-n-Irqi an enigmatic element can be seen: a small figure of a man in a jar. No satisfactory explanation for this detail has been found so far. Although a parallel representation seemed to have been discovered in Banganarti, it remains a unique and problematic representation. On the basis of a renewed investigation of the iconography of martyrs in the fourth century, the author proposes a new interpretation of the man in the vessel.
\end{abstract}

Keywords: Christian wall-painting, iconography, Abdallah-n-Irqi, Christian Nubia

Karel C. Innemée, University of Amsterdam, Amsterdam / University of Divinity, Melbourne; k.c.innemee@uva.nl

The Central Church of Abdallah-n-Irqi was excavated in 1963/1964 by a team from the National Museum of Antiquities, Leiden. In 1975 Paul van Moorsel published the mural paintings of the church and one of the paintings, that of a horseman, escaped a proper identification. ${ }^{1}$ In the same year László Török put a spotlight to a curious detail in this paintings: under the legs of the horse that most probably belongs to a warrior saint, a little bearded man in a vessel looks up at the rider, apparently calling for help (Fig. 1).

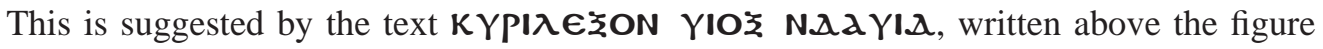
in the jar. ${ }^{2}$ A proper interpretation of the painting is hindered by the fact the upper part is missing and thus the identity of the man on horseback cannot be established. Where Török presumes that he is a saint, Van Moorsel initially uses the word 'horseman' in his description, but eventually, in the iconographical interpretation, calls him a saint as well. It seems indeed unlikely that the scene does not represent a warrior saint, given the fact that other warrior saints have been depicted in the same church. Neither Van Moorsel

1 Van Moorsel, Jacquet, Schneider 1975: 115-117. The painting, belonging to the layer that can be dated to the end of the tenth/beginning of the eleventh century, is located on the southern wall of the southern aisle, at the far eastern end.

2 Török 1975: 121-129. The hypothetical reconstruction of the text is from Török 1975: 122. The epigraphy as reproduced in Van Moorsel, Jacquet, Schneider 1975: 116, is far from clear, apart from the word kurilecon. 


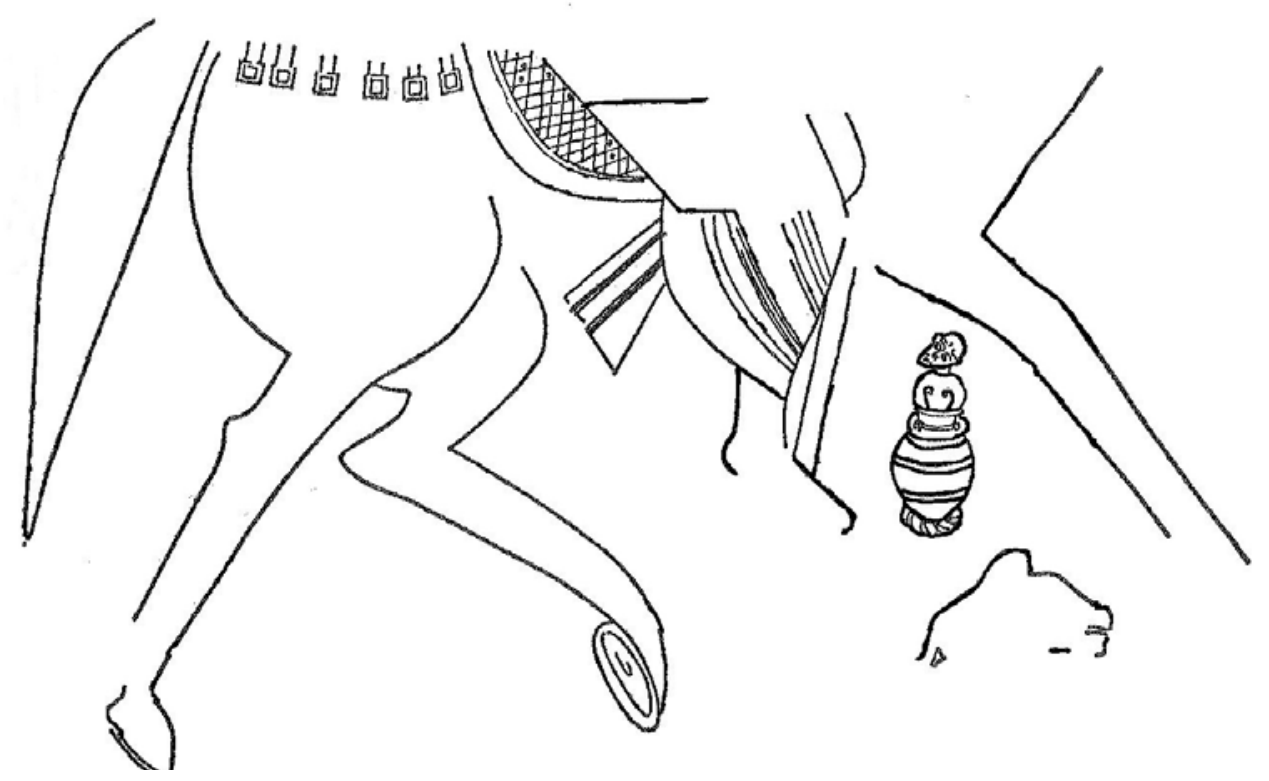

1. Horse riding saint, Abdallah-n-Irqi, Central Church, south wall (Drawing: K.C. Innemée; based on: Van Moorsel, Jacquet, Schneider 1975: 72).

nor Török, both apparently writing about the painting simultaneously and independently, come to a final and satisfactory conclusion concerning the interpretation of the painting and the identification of the horseman and the figure in the jar. This is not surprising, since comparable images of a man in a jar were not known in Christian iconography, neither legends of saints or martyrs, who were either locked up in a vessel or delivered someone from this awkward situation. One element in the painting may not have been given the attention it deserves: below the man in the vessel some lines are visible that are difficult to identify at first sight, but which may play a role in identifying the figure. This will be discussed later.

Recently, during the excavations by the Polish Centre of Mediterranean Archaeology of the University of Warsaw (1998-2014) of the church of Banganarti, a painting was discovered in which it seemed initially that the same theme was depicted. It concerns a painting on the western wall of the Upper Church, showing a standing warrior, of which only the lower part is preserved. He holds a spear, seemingly in his right hand, with which he pierces a figure under his left foot. Under his right foot there is a second figure, reaching out towards the warrior with his right hand in what can be interpreted as a gesture of speech. Around his waist there is a circular object that looks like the rim of a jar. ${ }^{3}$ After further uncovering

${ }^{3}$ Żurawski 2014: 204-205, Figs 3-5. The painting belongs to the twelfth century or later. 
and cleaning, however, it appeared that the lower part of the figure is visible and that he is not emerging from a vessel. ${ }^{4}$

The initial presumption that there were two examples in Nubian iconography of a man in a vessel, in combination with a warrior saint, was the stimulus for a renewed investigation into the meaning of this phenomenon. This question remains problematic. We should bear in mind that hardly any new evidence is available for a proper identification; no Christian texts concerning men in vessels have emerged meanwhile, so that the only way of approaching the matter is a return to the basic meaning of representations of warrior saints and a renewed look at men in jars in other contexts.

\section{WARRIOR SAINTS AND THEIR ORIGIN AND ICONOGRAPHY}

The cult of military or warrior saints has its roots in the persecutions of the third century, and many, if not most of them were the victims of purges in the army under the Tetrarchy. ${ }^{5}$ The question here is not whether these military saints in the ecclesiastical calendar were all historical characters; hagiography is not a form of history that meets modern standards and some of these warrior saints are fictional characters or on the basis of scant historical facts the stories of their lives were elaborated over time. ${ }^{6}$ The question is rather how the story of their life and martyrdom was used in the ideology and iconography of the respective churches where they were venerated. The Eastern Churches venerate numerous military saints and especially in the Coptic Church, whose calendar starts with the reign of Diocletian as a salute to the martyrs who died under his reign, they stand in high esteem. Two ways of depicting them are usual: in frontal standing position, or mounted on horseback. In the latter case the saint is often depicted in combat with some kind of opponent, representing Evil. In many cases this is an element taken from the life of the saint, such as St George killing the dragon, but often anachronistic details can be added, which in certain cases are based on later legends. St Mercurius, martyred under Decius, is often depicted in the act of killing Julian the Apostate, while St Demetrius, martyred under Diocletian, is represented sometimes while killing the thirteenth century Bulgar tsar Kaloyan. ${ }^{7}$ In other cases not even a legendary source can be found for a confused or confusing composition. In a recently discovered painting in Deir al-Surian (Egypt), a saint on horseback kills Diocletian and a certain Alexandros at the same time. ${ }^{8}$ No saint can be found to whom such mortal confrontations are ascribed. This in itself is not surprising. The image of the military saint on horseback does not show him as a martyr in the literal sense of the word,

\footnotetext{
${ }^{4}$ This information is based on a personal communication by Bogdan Żurawski, March 2019. At that moment the first version of this article had been finished already. The following text, therefore, concerns only the painting from Abdallah-n-Irqi.

${ }^{5}$ Helgeland 1974: 159-161; Sendeková 2013; Walter 2003 is the most recent comprehensive study into the tradition and iconography of warrior saints.

${ }^{6}$ Good examples are the two famous saints called Theodore and St Mercurius, Walter 2003: 44-66, 101.

7 Walter 2003: 130.

${ }^{8}$ Innemée, Ochała, Van Rompay 2015: 154-156.
} 
but as a victor over the forces of Evil and paganism, personified by monsters or rulers. Although in the literal sense he is the victim, iconography reverses the roles and the martyr becomes the victor in the spiritual sense, while his oppressor or the persecutor of Christianity takes the role of Evil subdued. ${ }^{9}$ The image of the equestrian saint is an allegory in the first place, not a narrative. As a result he can be depicted with opponents that do not necessarily belong to his hagiographical tradition. This 'flexibility' in the iconography of military saints is a certain handicap when it comes to using the identity of their victims to identify the saint.

\section{THE MAN IN THE JAR: AN ANONYMOUS MARTYR?}

Although the painting in Banganarti does not depict a man in a jar, it has one element in common with the man in the jar from Abdallah-n-Irqi: the saint is piercing an opponent, while he and the man in the (initially presumed) vessel do not seem to be attacked. This juxtaposition of the two figures confirms what Van Moorsel and Török presumed concerning the man in the vessel in Abdallah-n-Irqi: he is a not an opponent, but a victim, awaiting salvation from the saint. ${ }^{10}$ As noted above, no parallels in Christian iconography or hagiographical sources seem to refer to men in vessels and both Van Moorsel and Török could find no closer parallel than the story and the images of King Eurystheus, who hid himself from Hercules in a vessel, scared to death when the hero returned with the boar of Erymanthos and later with Cerberus. ${ }^{11}$ This iconography is well known from various monuments, for instance a metope from the temple of Hera at the mouth of the river Sele (Fig. 2a) near Paestum and a number of Attic vases (Fig. 2b). ${ }^{12}$ Although in its appearance, the figure of Eurystheus, appearing from the vessel with both arms raised, has a clear similarity with the detail of the man in the jar in the Nubian paintings, it seems difficult at first sight to see a connection between the labours of Hercules and Christian warrior saints. This connection, however, may be provided by a number of terra sigillata vessels from North Africa. In his study Voluptatem Spectandi non Perdat sed Mutet, Jan Salomonson presented a number of ceramic objects on which themes related to circus games and execution of early Christian martyrs are depicted. On several pieces and fragments of such lamps, bowls, and plates representations of men in jars occur and their meaning cannot always be explained unequivocally. On a fourth century lamp a man in a vessel, with raised hands is depicted (Fig. 3a). ${ }^{13}$ It has a great similarity with a fragment of presumably a plate, on which the same subject is depicted. ${ }^{14}$ Because of a lack of context (no other persons are depicted on these two pieces) the meaning is not clear. Salomonson compares them to two other plates, one where Hercules with the boar or Erymanthos is represented, facing

\footnotetext{
${ }^{9}$ For an elaborate study, see: Baumeister 1972.

10 Van Moorsel, Jacquet, Schneider 1975: 117; Török 1975: 122.

11 Brommer 1953: 18-20.

12 See website: Ancient Rome.

13 Salomonson 1979: 20, Pl. 11. The lamp is from the collection K. Löffler, inv. no. L59, in Cologne.

14 Salomonson 1979: 21, Pl. 12. The fragment is from the museum in Carthage.
} 

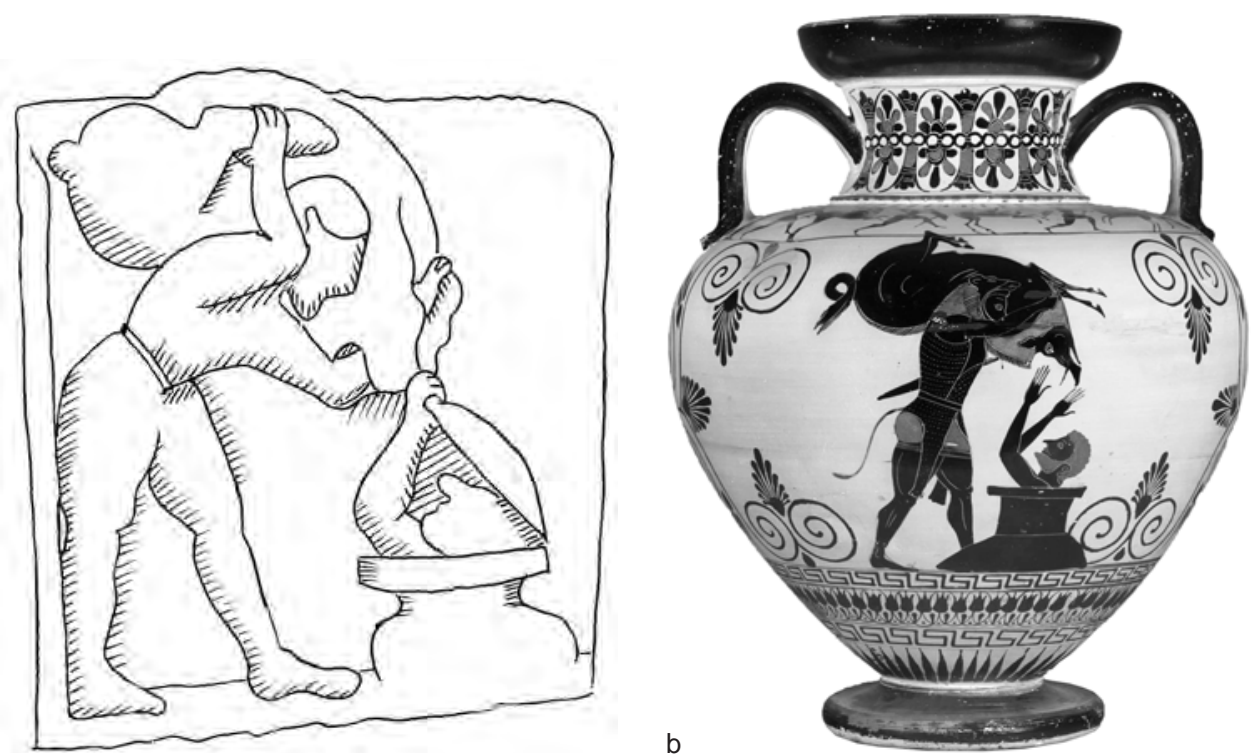

2. Hercules bringing the Erymanthian boar to Eurystheus: a. Paestum, Temple of Hera at the mouth of the river Sele, metope; b. black figured amphora, British Museum, inv. no. 1843, 1103.63 (a. drawing: K.C. Innemée; based on: Alamy Stock photo 181694463; b. courtesy of the British Museum).

Eurystheus in a large vessel, again with raised hands. ${ }^{15}$ On the other plate a man in a large kantharos is depicted, flanked by two jumping or running lions (Fig. 3b) ${ }^{16}$ Salomonson interprets this image, according to him derived from the previous theme, as a representation of Daniel in the lions' den, although he admits that the nudity of the man in the vessel is unusual, and that a kantharos is not a usual element in the biblical story.

The figures in relief on the terra sigillata vessels have been made with moulds, so that lions and human figures could be easily repeated in different configurations, thus creating different compositions with different meanings. The figure in the kantharos could have been combined with a figure of Hercules, thus giving it the meaning of Eurystheus, while lions could be used in combination with figures tied to poles, as representations of the circus games with criminals executed ad bestias.

What do we know about the means of execution as a form of public entertainment? Not all executions took place in circuses or arenas and not all the human victims of violent games were convicted criminals. Christians must have made up at least a part of the people who were killed for entertainment and the well-known account of the deaths of Perpetua and Felicitas can be considered a reliable description of such a case. ${ }^{17}$ To avoid boredom among the audience, the games needed new attractions regularly and the execution of

\footnotetext{
15 Salomonson 1979: 59, Pl. 46. The plate is from the collection K. Löffler, inv. no. N72, in Cologne.

16 Salomonson 1979: 55-56, Pl. 45. The plate is from the collection K. Löffler, inv. no. N77, in Cologne.

17 Hunink 2010.
} 

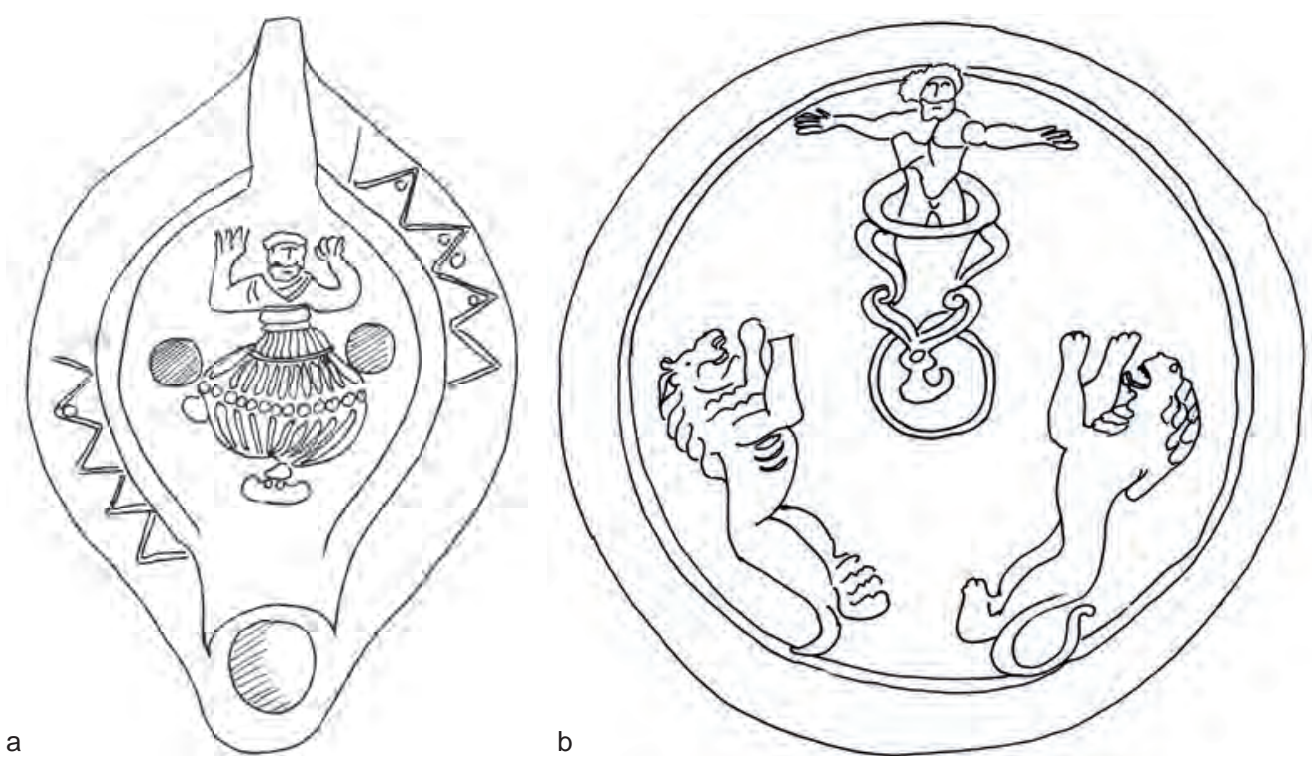

3. A man in a vessel represented on terracotta lamp (a) and terra sigillata (b) from the collection of K. Löffler in Cologne, inv. nos L59, N77 (Drawing: K.C. Innemée; based on: Salomonson 1979: Pls 11, 45).

convicted criminals (including Christians) could not always be a matter of simply exposing them to hungry animals, and theatrical stagings were invented to make the spectacle more attractive. This included scenes from mythology in which a main character would meet his or her death. The most famous example known to a wide public is of course the death of Lygia in the novel 'Quo Vadis' by Henryk Sienkiewicz, when Lygia is tied to the horns of a bull, who crushes her to death, a re-enactment of the death of Dirce, the wife of king Lycus of Thebes. She was killed by the sons of Antiope, as a revenge for treating her cruelly. The fictitious event from the novel is based on the first epistle to the Corinthians (6:2) by Clement of Rome, where he mentions the martyrdom of Christian women: Because of jealousy, women were persecuted as Danaids and Dircae, suffering in this way terrible and unholy tortures, but they safely reached the goal in the race of faith and received a noble reward. ${ }^{18}$ This is apparently an allusion to the persecution and execution of Christians by Nero, and although Clement gives no details, it can be interpreted as a description of how the executions were turned into mythological role-plays. ${ }^{19}$ This way of enhancing the entertaining value of executions in the framework of circus games was not limited to the times of Nero and not to Rome either. Tertullian criticises and mocks the way gods and mythological characters are used in profane performances and particularly in the deadly games and executions in the arena. ${ }^{20}$ Especially Hercules was a popular figure, since scenes

\footnotetext{
18 Holmes (Ed.) 2007: 53.

19 Champlin 2003: 123-125.

20 Tertullian, Apology, 15.
} 
from his life and death offered the opportunity of ending the performance with a crematio, burning the victim alive. ${ }^{21}$ Kathleen Coleman uses the term 'fatal charades' for such dramatised executions and shows how such ludi meridiani (early afternoon performances) had a combined function of showing how justice was maintained and criminals were punished while entertaining a wide public. ${ }^{22}$ The pleasure of watching gladiators fight for their life or criminals being devoured by wild animals was not restricted to those exciting afternoons in the circus, but the memory of it could linger on while watching the floor mosaics depicting the same themes that some of the wealthy could afford to commission, or, in the case one was not that well-off, the terra sigillata plates and bowls with similar decoration. ${ }^{23}$ Although Christianity was gaining influence in fourth-century North Africa and many Christians had objections against what they considered cruelty, such themes continued to be depicted. Salomonson presumes that the images on the vessels, showing damnati tied to poles and attacked by beasts were still made from the same moulds and did not change in their appearance, but that the appreciation changed from the pleasure of seeing suffering to being reminded of the fate of the martyrs. ${ }^{24}$ If we apply that thought to the interpretation of the plate with the man in the kantharos, flanked by two jumping lions, we could come to the following hypothetical conclusion. The mould for the man in the kantharos, one of the many that the pottery workshop must have had on the shelf, could be used in combination with a figure of Hercules, thus taking the meaning of king Eurystheus hiding in a jar. But, considering that the stories of the life of Hercules were apparently popular for the 'fatal charades' in the arena, and that jumping lions were also used in plates and bowls depicting scenes of execution/martyrdom, the scene with the nude man emerging from the jar can also be read as such a scene in the arena, where the damnatus was forced to play the role of Eurystheus. This time he is hiding, not from Cerberus or the Erymanthian boar, but from the lions that have been set loose. The scene on the plate is not necessarily referring to one specific person, but to the phenomenon of damnati/martyrs in the arena in a mythological re-enactment. In all probability the theme of the man in the vessel can be counted among the many representations of the third and early fourth century that have an ambiguous meaning, depending on its context: the sheep bearer, the orans/orante, the Jonah/Endymion reclining figure, etc. The man in a jar depicted on an oil-lamp (see Fig. 3a) may have been such an example of how the same object can be viewed differently by a Christian or pagan owner.

How common was the subject in early Christian times? Just a handful of examples have survived, apparently all from North Africa. That stands in contrast to other themes with an ambiguous meaning that have been found in great numbers, but an explanation for this could be that the themes mentioned above have a funerary significance, and objects from

${ }^{21}$ Coleman 1990: 60.

${ }^{22}$ Coleman 1990: 54.

${ }^{23}$ Salomonson 1979: 42-50.

${ }^{24}$ Salomonson 1979: 42-50. This is what the title of his book alludes to: Voluptatem spectandi non perdat sed mutet, quoted from a sermon of the Carthaginian bishop Quodvultdeus; Salomonson 1979: 89. 
funerary contexts are more likely to survive the centuries. Furthermore, scenes of torture and execution of martyrs were apparently not popular in early Christian and early Byzantine art; martyrs are rather depicted in a dignified and victorious way, holding a palm branch or with a wreath being offered to them. ${ }^{25}$

\section{CONCLUSION}

In many representations of warrior saints a hostile person or animal is represented as being attacked or killed by the saint, often referring to legends from the saint's life. Sometimes such opponents are not identifiable or directly related to hagiographical sources, and meant as more general personifications of Evil or oppression. ${ }^{26}$ In the case of the painting of the saint and the man in the jar we have no hagiographical information and we can only say that the man in the jar stands for the oppressed and this implies that an oppressor, as adversary of the saint, must be depicted elsewhere. If we summarise the position of the man in the vessel it is clear that he is in distress and that the saint is the one invoked to help them. There seems to be no trace of an opponent of the saint, like in Banganarti, but a closer look at the lines below the man in the jar may give a clue. Although vaguely preserved, they show what seems to be the profile of a lion's head and that would support the interpretation of the man in the jar as someone attacked by lions (Fig. 4). If these are indeed the faint traces of a lion, it was not shown attacking the man in the jar, but in profile, possibly trampled by the legs of the horse.

If it seems difficult or even impossible to retrieve the identity of the man in the jar, this may not be a matter of missing evidence, but rather of asking the wrong question. As on the bowls and in the mosaics from North Africa, where the victims of execution are not specific individuals, but rather images of victims in general, the man in the jar from Abdallah-n-Irqi may probably be read as a prototype of Christian martyrs, in the same way that the rulers killed by the equestrian saints are personifications of the forces of Evil, overcome by the virtue of the martyr.

The question that remains is how this iconographical detail arrived in Nubian iconography. No other examples from the Byzantine or Coptic reach are known where an equestrian saint is confronted with a man in a jar. The North-African terra sigillata vessels and the Nubian paintings are centuries apart and a direct connection between them seems highly unlikely. That does not imply that there is no connection at all. In a periphery remnants of certain phenomena can survive, where in the centre all traces are lost. It would of course be a gross underestimation to label Nubian culture as peripheral, but in this respect, the iconography of equestrian saints, the models and sources of inspiration were in all probability Byzantine or Coptic. The iconography of the martyr on horseback is not a part of indigenous Nubian culture and was imported from regions farther north. The trail along

${ }^{25}$ Representations of the actual martyrdom of a saint, such as that of St Laurence on a fifth-century medallion, are rare. Grig 2004: 224, Fig. 12.

26 See: Innemée, Zielińska 2019. 

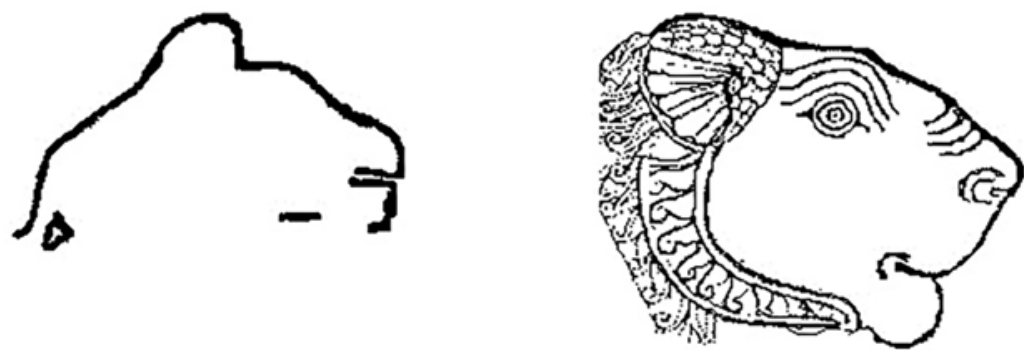

4. Detail of the painting in Abdallah-n-Irqi, and profile of Meroitic lion head (Drawing: K.C. Innemée; based on a relief on the southern wall of the Apedemak temple in Mussawarat al-Sufra).

which the motif of the man in the jar must have travelled, however, remains unknown. The absence of evidence may have various reasons. In the third an early fourth centuries executions in the arena were depicted in mosaics, on lamps and bowls, but in Christian iconography the prevalent image of the martyr became that of the dignified, victorious person. It remains unknown whether the man in the jar has its origin in legend, referring to a specific character or whether he is a nameless martyr or victim. More probable is the latter option. If the motif of the man in the jar has survived on a limited scale in the context of the image of the warrior saint, then iconoclasm has probably obliterated most of its examples. Also in Egypt, where iconoclasm has not had an effect, few paintings of warrior saints from before the tenth century survive and in none of them does a trace of a man in a jar occur. ${ }^{27}$ The man in the jar in the painting from Abdallah-n-Irqi is probably a rare relic of an iconography with roots in the fourth century.

\section{References}

Ancient Rome: http://ancientrome.ru/art/artworken/img.htm?id=5184 (accessed August 24, 2018)

Baumeister, T. 1972: Martyr Invictus. Der Martyrer als Sinnbild der Erlösung in der Legende und im Kult der frühen koptischen Kirche. Zur Kontinuität des ägyptischen Denkens, Münster

Brommer, F. 1953: Herakles: die zwölf Taten des Helden in antiker Kunst und Literatur, Münster

Champlin, E. 2003: Nero, Cambridge MA

Clédat, J. 1904: Le monastère et la nécropole de Baouît, MIFAO 12, Le Caire

Coleman, K.M. 1990: Fatal Charades: Roman Executions Staged as Mythological Enactments, JRS 80, 44-73

Grig, L. 2004: Portraits, Pontiffs, and the Christianization of fourth-century Rome, PBSR 72, 203-230

${ }^{27}$ The mural paintings from Bawit and in Deir al-Surian are some of the few examples. Clédat 1904: Pls LIII, LV; Innemée 2016: 10-11. 
Helgeland, J. 1974: Christians and the Roman army A.D. 173-337, ChHist 43/2, 149-163, 200

Holmes, M.W. (Ed.) 2007: The Apostolic Fathers: Greek Texts and English Translations, Ada MI

Hunink, V. 2010: Did Perpetua write her prison account?, ListFil 133/1-2, 147-155

Innemée, K. 2016: Dayr al-Suryan: New Discoveries, [in:] Claremont Coptic Encyclopedia, http://ccdl.libraries.claremont.edu/cdm/singleitem/collection/cce/id/2137 (accessed June 20, 2019)

Innemée, K., Ochała, G., Rompay, L. van 2015: A Memorial for Abbot Maqari of Deir al-Surian (Egypt): Wall Paintings and Inscriptions in the Church of the Virgin Discovered in 2014, Hugoye 18/1, 147-190, https://hugoye.bethmardutho.org/ article/hv18n1crinnemee (accessed June 20, 2019)

Innemée, K., Zielińska, D. 2019: Faces of Evil in Nubian Wall-Painting - An Overview, EtudTrav XXXII, 121-144

Moorsel, P. van, Jacquet, J., Schneider, H. 1975: The Central Church of Abdallah Nirqi, The Netherlands excavations in Nubia, Abu Simbel North 1962-1964, Leiden

Salomonson, J.W. 1979: Voluptatem Spectandi non Perdat sed Mutet, Observations sur l'iconographie du martyre en Afrique Romaine, Amsterdam-Oxford-New York

Sendeková, M. 2013: The Persecution of Christians in the Roman Army in the Late $3^{\text {rd }}$ and Early $4^{\text {th }}$ Century, Kultúrne Dejiny 4, Supplement, [Ružomberok], 14-24

Tertullian, Apology: The Apology of Tertullian, transl. and annotated W. Reeve; The Meditations of the emperor Marcus Aurelius Antoninus, transl. J. Collier, LondonSydney [1889]

Török, L. 1975: Man in the vessel; an Interpretation of a Nubian Fresco Representation, [in:] Michałowski, K. (Ed.), Nubia. Récentes recherches. Actes du colloque nubiologique international au Musée National de Varsovie, 19-22 juin 1972, Warsaw, 121-125

Walter, C. 2003: The Warrior Saints in Byzantine Art and Tradition, Aldershot

Żurawski, B. 2014: Kings and Pilgrims. St Raphael Church II at Banganarti, mid-eleventh to mid-eighteenth century, Nubia V, Banganarti 2, Warsaw 


\section{ÉTUDES et TRAVAUX XXXII / 2019}

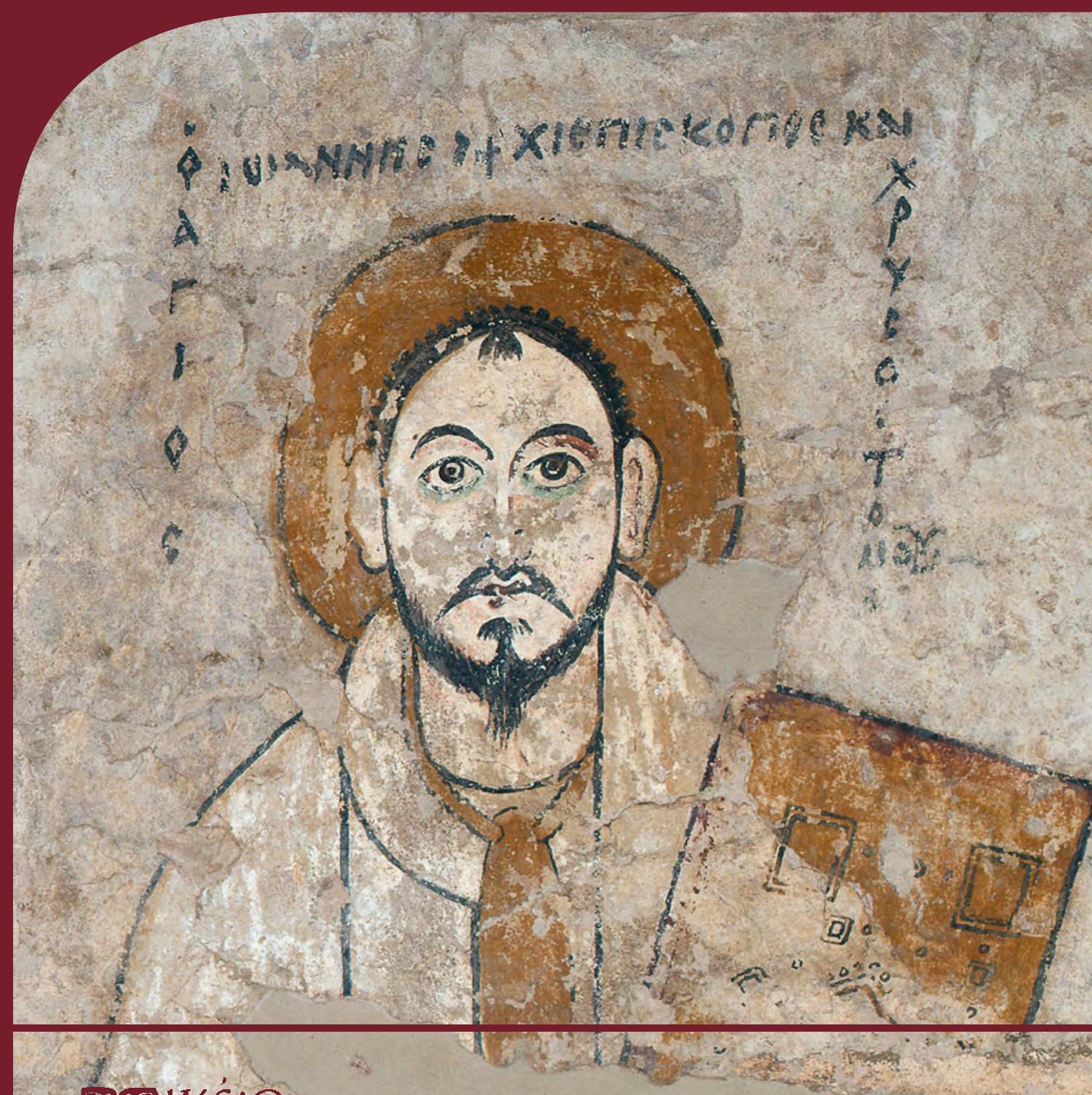

BOMIKSiO Institut des Cultures Méditerranéennes et Orientales ED2A PAN de l'Acácémie Polonaise des Sciences 


\title{
COMITÉ DE RÉDACTION SCIENTIFIQUE
}

Maciej Makowski - rédacteur en chef Jadwiga Iwaszczuk - rédacteur

Maciej G. Witkowski - rédacteur

Agnieszka Ryś - sécretaire de la rédaction

Bogdan Żurawski - rédacteur thématique du volume

CONSEIL SCIENTIFIQUE DU JOURNAL

M. Kobusiewicz (IAE PAN, Warszawa), E. Laskowska-Kusztal (IMOC PAS, Warszawa),

D. Michaelides (University of Cyprus, Nicosia),

J.Ch. Moretti (IRAA-MOM, Université de Lyon 2/CNRS),

D. Raue (Ägyptisches Museum der Universität Leipzig), P. Reynolds (ICREA, España),

D. Welsby (British Museum, London)

\section{COMITÉ SCIENTIFIQUE DE LECTURE}

D.E. Arnold (Wheaton College/The Field Museum, Chicago), H.D. Baker (University of Toronto),

P. Ballet (ArScAn-ESPRI, Université Paris Nanterre), Ch. Barber (Princeton University),

N. Beaux-Grimal (IFAO, Caire/Collège de France, Paris), A. Boud'hors (CNRS, IRHT, Paris),

J. Budka (Ludwig-Maximilians-Universität München), R. David (SFDAS),

A. Delattre (CPEG, Bruxelles), A. Dodson (University of Bristol),

E. Fogliadini (Facoltà Teologica dell'Italia Settentrionale, Milan),

V. Francigny (CNRS/CRES, Paris), L. Gabolde (CNRS), C. Gobeil (Egypt Exploration Society, London),

N. Hamdi (UCL, Louvain), J. den Heijer (CIOL/INCAL, Louvain-la-Neuve),

S. Ikram (American University in Cairo), Ch. Leitz (Universität Tübingen), S. Ortisi (Universität München),

E. Rova (Università Ca' Foscari Venezia), G. Ruffini (Fairfield University),

A. Sasson (San Diego Natural History Museum), H. Satzinger (Universität Wien),

S.M. Schellinger (The Ohio State University, Columbus), G. Schreiber (Eötvös Loránd University, Budapest),

E. Teeter (University of Chicago), S. Torallas-Tovar (University of Chicago),

Y. Tristant (Macquarie University, Sydney), V. Vaelske (independent researcher),

H. Vymazalová (Charles University, Prague), P. Weschenfelder (Universität Wien),

B. Williams (University of Chicago/PCMA UW, Warszawa),

K. Winther-Jacobsen (The Danish Institute at Athens), E. Zacharopoulou (University of Johannesburg),

P. Grotowski (UPJPII, Kraków), E. Papuci-Władyka, J. Śliwa (IA JU, Kraków), A. Ćwiek (IA AMU, Poznań),

K.O. Kuraszkiewicz, M. Pinker (FOS UW, Warszawa), Ł. Niesiołowski-Spanò (IH UW, Warszawa),

M. Gawlikowski, Mahmoud El-Tayeb (PCMA UW, Warszawa), S. Rzepka (IA UW, Warszawa)

\author{
RÉDACTION TECHNIQUE \\ Monika Wesołowska
}

REVUE DES TEXTES ANGLAIS

Jo Harper 
ÉTUDES et TRAVAUX

XXXII 
INSTYTUT KULTUR ŚRÓDZIEMNOMORSKICH I ORIENTALNYCH POLSKIEJ AKADEMII NAUK

\title{
STUDIA i PRACE
}

\author{
XXXII
}

gू IKŚiO

ESAN

WARSZAWA

2019 
INSTITUT DES CULTURES MÉDITERRANÉENNES ET ORIENTALES DE L’ACADÉMIE POLONAISE DES SCIENCES

\section{ÉTUDES et TRAVAUX}

XXXII

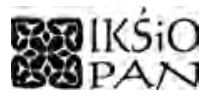

VARSOVIE

2019 
Publication scientifique financée dans le cadre du programme du Ministre de la Science et de l’Éducation Supérieure

« Programme National de Développement de l’Humanistique » pour les années 2016-2021 (projet no $3 b H 150099$ 83)

\title{
TI NARODOWY PROGRAM ROZWOJU HUMANISTYKI
}

\author{
Copyright $(\mathbb{C}$ \\ Instytut Kultur Śródziemnomorskich i Orientalnych PAN \\ et les Auteurs \\ Warszawa 2019
}

\begin{abstract}
ISSN 2084-6762
(avant 2011 : 0079-3566)

e-ISSN 2449-9579

Version première en papier, imprimée en Pologne - 150 copies

Version électronique accessible sur

http://www.etudesettravaux.iksiopan.pl
\end{abstract}

Édition: Polskie Towarzystwo Historyczne et Wydawnictwo Neriton, Warszawa

Conception générale de couverture : J. Iwaszczuk

Photo de couverture : P. Ligier ; courtoisie du Musée National de Varsovie

(Saint Jean Chrysostome, peinture, cathédrale de Faras). 


\section{Table des matières}

Editorial: Quid novi ex Nubia (par Bogdan Żurawski) ............................................... 7

Bibliography of Professor Stefan Jakobielski ................................................................ 13

Aneta Cedro, Bogdan Żurawski

Living with the Past in Modern Sudanese Village. Traditional Pottery Production

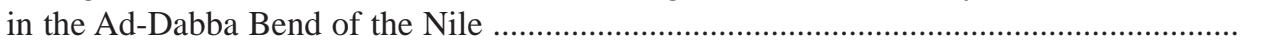

DAVID N. EDWARDS

A Possible Monastery and the 'Upper Maqs’ at Ukma-Akasha West? ............................ 53

Vincent W.J. van GeRven OeI

An Old Nubian Curse from the Faras Cathedral ........................................................ 81

Vincent W.J. van Gerven Oei, Adam Łajtar

Two Old Nubian Inscriptions from Akasha West ........................................................ 89

Vincent W.J. van Gerven Oei, Alexandros Tsakos

Rubrication Patterns in Two Old Nubian Manuscripts from Serra East .......................... 99

KAREL C. INNEMÉE

A Man in a Vessel, Once More .................................................................................. 111

KAREL C. INNEMÉE, Dobrochna ZielińSKA

Faces of Evil in Nubian Wall-Painting - An Overview ................................................ 121

ADAM ŁAJTAR

Epitaph of Merki Found in Hambukol ....................................................................... 145

MAGDALENA ŁAPTAŚ

Attributes, Vestments, Context and Inscription in the Identification of Nubian

Paintings: Proposing the 'Multi-Layer' Image Recognition Method ............................... 161

Grzegorz Ochala

Nubica Onomastica Miscellanea I: Notes on and Corrections to Personal Names

Found in Inscriptions from Faras 


\section{Robin SEIGNOBOS}

L'influence du Kitāb ahbār al-Nūba d'Ibn Sulaym al-Uswānī sur l'Histoire des églises et monastères d'Égypte d'Abū al-Makārim

JACQUES VAN DER VLIET

Exit Bishop Tamer - the Sequel. A New Edition of the Epitaph of Papsine alias Doulista (DBMNT 78) 